\title{
Theoretical and Practical Significance of the Teaching Folklore in the Education Stages
}

\author{
Nazokat Yusufjonova Nigmadjonovna \\ Tashkent State University of Uzbek language and Literature Named after A.Navoi, PhD student \\ Tashkent, Uzbekistan
}

\begin{abstract}
Today's unique development is owing to the implementation of the initiatives on development of the education, improvement of the quality of the education, improving the role and place of the teachers in the society and appreciating their deeds. Studying folklore, which reflect understanding and showing individuality of a nation, motivations, life style and outlook, is to study history of ethnos, their customs, traditions, feelings, past, present and future. Popular epics play an important role in the spiritual perfection of the mankind.

There has analyzed significance of the studying folklore in the educational system of Uzbekistan and educational, training, and developing aims of the lesson which dedicated to teach Uzbek and Indian folk epics on the basis of comparative-typological analysis were structured in this article.
\end{abstract}

Key words: comparative training, method of teaching, narrative folk tales, education program, folklore, traditional motifs, comparative analysis.

\section{Introduction}

The folklore, created many centuries before the written literature, has been living on up to these days. The Uzbek folklore, which served as a great source in the formation of the written literature, includes many genres such as poems, legends, tales, songs, sayings and riddles, and they reflect the history, domestic culture, traditions and mentality of the nation. the history of poetic thought of the Oriental peoples is of common origin such as symbols, artistic style, ideas of glorification of human being, comprehension of human beings and the world, faithfulness, loyalty in its philosophical nature found in these epics share the same roots. Meanwhile divine support and recognition of positive creativity i.e. psychology of artistic creativity are reflected in them. By their nature the epic motives are in harmony with mythological and religious and traditional views.

According to the "Education program for the secondary education" for the subject of literature approved in 1999 by the "State standards of the secondary education", the content of the meaning of the subject of literature includes the studying the unique samples of folklore of Uzbek, fraternal and foreign nations, forming the skills of understanding and analyzing the read eposes, their comparative analysis by comprehending the theoretical information, and development of the pupils' oral and written skills.

Main part: The samples of the folklore - sayings, tales and riddles are taught from the $5^{\text {th }}$ grade.

The information about folk songs, such as "Boychechak", "Chittigul", "Khup mayda", "Yor-yor" and "Kelin salom" and their kinds are brought in the $6^{\text {th }}$ grade.

For the $7^{\text {th }}$ grade, 4 academic hours are allowed to study "Ravshankhon" love-adventure poem from "Gurugli" series and to learn about the art of hyperbole. 
A four-hour study is allocated to study the variation of Kuntugmish" poem sung by Ergash Djumanbulbul for the $8^{\text {th }}$ grade where pupils learn the formal structures of the poems, analyze the wealth of adventures in the plot, proximity of the events which determine the fate of the heroes to the daily life, the appearance of the features of courage, generosity and naivety which is specific to the Kuntugmish's character, his features as a warrior, a lover and a father, the description of Kholbeka as valiant, naughty, kind woman ready to sacrifice for the sake of her children and beloved which is common for Uzbek girls, Gurkiboy's calmness, kindness and thoughtfulness, his brother Mokhiboy's obstinacy and artfulness, and also specific interpretation of the characters such as Buvrakhon, Azbarkhodja, Kasym, Kholmumin, a shepherd.

According to the "Education program for the secondary education" "Alpomish" poem is included in the curriculum of the $9^{\text {th }}$ grade. Five hours are allocated to the study of the heroic poem of the uzbek people, and in this course pupils study the poem's role in the formation of the culture and spirituality of the Turkic nations, the relation of the content of the poem to the Turkic ethical mentality and Turkic statehood, the description of the features such as courage, loyalty, good through the characters of Alpomish, Koradjon, Oybarchin, and Kaldirgoch, and language peculiarities of the poem. Special attention is paid to the places where the description of Uzbek mentality and traditions are given. Theoretical information about Fozil Yuldosh ugli's deeds, which enabled us to get acquainted with the poem, the schools of bakhshi, and also folk poems and their types is learned.

The textbooks of the secondary and special education contain the "Ravshankhon" poem, where students analize the events and characters for 2 sessions.

The first-year students of the academic lyceums study the information about the Uzbek folk poems, talented bakhshi of our nation, and the schools of bakhshi in the first semester during the course of "Folklore". Also, during the course the students get information about the mutual impact of the folklore and literature, the types of the folklore: songs and lyrical poems, legends and tales, loveadventure poems, their community, conditionality and diversity.

For the institutions of higher education, especially for the first-year students study of " $\boldsymbol{U} \boldsymbol{z b} \boldsymbol{e k}$ folklore" is implemented into the curriculum and education program, and its objective is teach students the peculiarities, development stages of the folklore, its genres, and to analyze them thoroughly, and to raise the students in the spirit of high spirituality, loyalty to universal values and love of the cultural heritage. In this course, the students should gain the theoretical knowledge about the inseparability of the Uzbek folklore from the literature, its peculiarities, genres, methods of performance, conditionality of the description.

In "Uzbek folklore" course the following skills are formed:

$\checkmark$ lectures, seminars, rating systems are used as means of education;

$\checkmark$ the students are required to possess the methods of collecting, maintaining, processing and applying the information.

It is also required that the students should know how to analyze, come to certain conclusions, apply the knowledge of the major tendencies of Uzbek folklore.

Within the framework of the issues while mastering the subject the bachelor should know:

$\checkmark$ the pecularities of uzbek folklore,

$\checkmark \quad$-the system of genres of uzbek folklore, and the peculiarities of each genre;

$\checkmark$ the life and works of the outstanding poets and bakhshis;

$\checkmark$ national and religious-philosophical beliefs about uzbek folklore; 
$\checkmark$ to collect the samples of Uzbek folklore;

$\checkmark$ to study the development stages of Uzbek folklore;

$\checkmark$ to apply the knowledge about Uzbek folklore;

$\checkmark$ to analyze the samples of Uzbek folklore.

The lectures include the themes on "Uzbek folk poems" and "The folklore of the fraternal nations", which denotes the reflection of the historical reality in the generalized ideal characters on the basis of the people's fantasy, the role and importance of the folklore in the literary thought of the world nations, giving more information about the folklore of the fraternal nations, particularly, about the Kazakh, Kara-kalpak, Bashkir, Tatar, Tadjik and other variations of "Alpomish" poem, fraternal variations of "Gurughli" series, "Manas", common epic works of the Turkic nations - "Kitobi Dadakurkut", ideological-literary harmony of the Indian people's "Mahabharata" and "Ramayana" with the eposes of other nations.

As they reflect ideals of the nation, the heroes in eposes are usually described physically strong, and mentally sound. There are many specific features in epic traditions in Uzbek and Indian folklore such as poetic transformation of archaic plots, copying epic plot and mythological interpretation and illustrating sequence of events fantastically and in mythological way. For example, the plot of many Uzbek eposes and stories and Indian epos "Ramayana" are connected with the birth of the heroes with supernatural power and wills of the earth and the sky and the heroes start their journey looking for love. Besides, the heroes are created with the features like hardship, bravery, faithful and perfect person.

At the same time, divine promotion and creativity, that is to say psychology of literary creativity is reflected in them. For instance, sage Valmiki who lived XXV centuries before now and ascribed Ramayana expressed divinity and promotion of saints. The features like wisdom, astuteness, quick wit, smartness of the heroes of "Alpomish", "Gurughli, "Ravshanxon" eposes are still involving the readers.

Symbols that were used in Uzbek eposes and their interpretation style, honouring a person in ideological and philosophical way, realizing humanity and the world and links between them are close to "Ramayana" and "Mahabharata". There are various similar and distinctive features between poetic structures, epic migration of the plot, mythological interpretations, especially, anthrop genetic myths' plot, typological variants of characters in traditional motifs of Uzbek and Indian eposes.

We see that sequences in mythological works are mythic and fantastic. According to mythological norms, there is no division (separation) between real and fantastic life. It has only nature and society. However, the other has the sky, mountains, plants, and life. Even, gods in "Ramayana" are not free from human advantages and fallibilities. They also argue and compromise. They help people to form life style, to solve problems, to overcome difficulties and to achieve goals. In general, in all periods and places, poets and writers do not distinct sharply from their ancestors not only in ethnic origin, but also inner world, spiritual level of perfectness and realizing the world poetically.

Women characters in eposes symbolize endurance, loyalty, smartness, bravery and wills and their interpretation widened the scope of aesthetic ideal view immensely.

As a teacher we need to pay attention to study of philosophical nature of Oriental epics, its ideological content, the system of motives of birth-journey-ordeal-marriage, semantics and their comparative classification according to their meanings and tasks during the teaching of eposes to the students.

Educational aim of the lesson which dedicated to teach Uzbek and Indian folk epics on the basis of 
comparative-typological analysis: educational explanation to the students that oral epic is expression of people's thought, analyzing their philosophical main point and educational significance and comparing Uzbek and Indian poems' heroes symbols and occurrences, besides, improving the students' knowledge.

Training aim of the lesson: educating students as generous, faithful, patient, patriot, perfect, sharp, resourceful, just like heroes of "Alpomish", "Ramayana", "Mahabharata" and other poems.

Developing aim of the lesson: memorizing passage from dastans, re-telling contents of a poem, thinking logically and creatively, using the time productively, to form a skill that working in a small groups during the lesson.

\section{Pedagogical tasks in this lesson:}

$\checkmark$ carrying out the aim which was indicated in the educational program;

$\checkmark$ explanation similarity and difference of East people's poems;

$\checkmark$ informing that oral epics serves improving spiritual life and thought of humanity during the centuries.

We usually create a Technological map of the practical training before organizing it. So teacher makes the questions for strengthening last theme; prepares necessary materials for the explaining new theme; makes mini-lecture, presentation and forming necessary sources list for the using during the learn on the aforementioned theme till the lesson.

I. Introduction training. At the beginning of the lesson teacher

gives and interpretes themes and sources list;

$>$ introduses with the theme, plan, aim and maintenanse of training's activity and creates "Golden rules" of the lesson with students;

$>$ gives key words and word expressions;

$>$ gives following questions for strengthening the knowledge of students:

$>$ What kind of Uzbek and Indian poems do you know?

$>$ Can you give us short information about uzbek narrators and school of implementing dastans?

> Have you ever heard about indian oral epic "Ramayana" and "Mahabharata"? Tell us about them.

$>$ Can you tell us names and their characters of heroes of "Alpomish", "Gurugli”, "Ramayana”, and "Mahabharata" poems?

Students give their oppinion and answer to the questions. They can write their answers to the special card and stick to a paper tree.

II. Spiritual time. Teacher can show video-record from "Alpomish" poem which has performenced by narrators (bakhshi).

III. Basic step. In this basic part of the lesson teacher

$\checkmark$ informs basic information on the theme using multi-media;

$\checkmark$ makes "Mental attack" on oral epics;

$\checkmark$ uses "Venn diagram" for strengthening the theme and improving knowledge on comparative analyze of students. Teacher should explain peculiarities and common aspects seen in epic 
heroes' activities such as setting out to journey, encountering obstacles, bravery shown while afoot and adventures both in Uzbek and Hindu epics.

In the strengthening time students are divided into small groups on the basis special cards. They compare similarity and difference of uzbek and indian poems by "Venn diagram". Answers will discuss together at the end of the all groups' presentation.

THE EPIC "ALPOMISH" SIMILARITY THE EPIC "RAMAYANA"

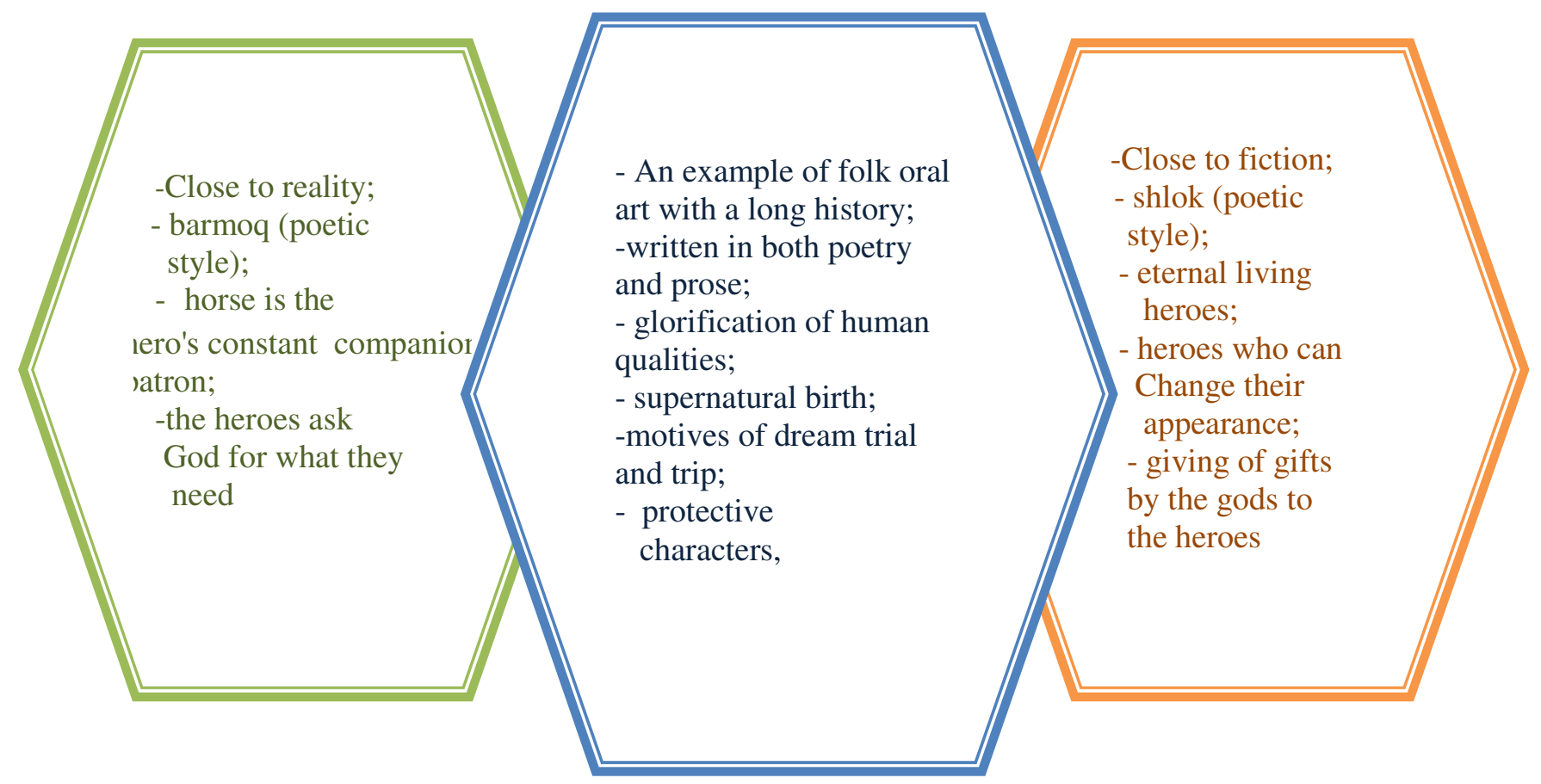

IV. Final step. At the end of the lesson teacher

$\checkmark$ gives the answers to the questions which have given by students on the theme;

$\checkmark$ concludes the training and marks students who have attended activly during the lesson;

$\checkmark$ gives the task rereading the eposes and filling a schedule named "Find suitable answer" for homework.

Students write their personal opinion to the special colorful card about the lesson and stick to the flip chart.

Conclusion: Result of process of comparative analytical lesson:

$\checkmark$ students realize that learning other countries poems gives opportunity getting acquainted to their culture and life;

$\checkmark$ they understand that nation's spiritual life, dreams, customs and tradition is expressed in the national poems, besides, being strong, patriot, generous is the most important thing in the reaching the goals of humanity;

$\checkmark$ they learn our great spiritual heritage's essence which has created by talented persons of the nation.

So we can see that divine heroes, images of patrons, everlasting characters, conflicts between the good and evil have inevitably enriched world popular folklores, especially Oriental mythology and 
epic artistry.

History of understanding of oriental nations is given by the symbols used in their eposes, literary style, philosophical essence, and the similarities of ideas such as praising a person that is shown by ideological form, loyalty in love, keeping the promise and having the only root for these literary masterpieces.

Actually, through these creative and imagination one doesn't separate himself from natural environment - real world. He only comprehends the reality in the shape of mythology.

\section{REFERENCES:}

1. Yuldoshev. K. Adabiyot uqitishning ilmiy-nazariy asoslari. T., Uqituvchi, 1996.

2. Rajabova I. Adabiyot darslarini interfaol usullarda tashkil etish. T., Tamaddun, 2010.

3. Alpomish. T., Sharq, 1998.

4. Ramayana. T., Ghafur Ghulom, 1978.

5. Jirmundskiy V., Zarifov Kh.. Uzbekskij gerojicheskij epos. M., OGIZ, 1947.

6. O.Avlayev, S.Djurayeva, S.Mirzayeva. Ta'lim metodlari. T., Navruz, 2017.

7. G.Amirova, O,Avlayev, U.Butayeva. Ta'limda interfaol metod va treninglar. T., Navruz, 2018. 